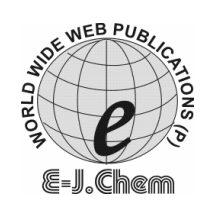

http://www.e-journals.net

ISSN: 0973-4945; CODEN ECJHAO

E-Journal of Chemistry

2009, 6(4), 1240-1246

\title{
Corrosion Study of Metals in Marine Environment
}

\author{
R. T. VASHI and H. K. KADIYA* \\ Department of Chemistry, Navyug Science College, Surat-395009, Gujarat, India. \\ ${ }^{*}$ C. U. Shah Science Science College, Ashram road, Ahmedabad-380014, India. \\ hitesh_1330@yahoo.co.in,vashirajendra@yahoo.co.in
}

Received 4 March 2009; Accepted 24 April 2009

\begin{abstract}
Atmospheric corrosion rate of $\mathrm{Al}, \mathrm{Zn}$ and mild steel (MS) as well as salinity and sulphation rate have been determined under outdoor exposure at Tithal (Dist. Valsad) situated in South Gujarat, India. MS samples exposed vertically suffer less corrosion than those exposed at an angle of $45^{\circ}$. Monthly corrosion rate was in the decreasing order of $\mathrm{Al}<\mathrm{Zn}<\mathrm{MS}$; whereas yearly rate also follow the same trend.
\end{abstract}

Keywords: Marine Environment, $\mathrm{Al}, \mathrm{Zn}$ and MS metals, Salinity and Sulphation rate.

\section{Introduction}

The corrosiveness of a marine environment depends on the topography of the shore, wave action at the surf line, prevailing winds and relative humidity. While the corrosiveness decreases rapidly with increasing distance from the shore, severe storms can carry salt spray inland as much as $15 \mathrm{~km}$. A marine atmosphere is laden with fine particles of sea salt carried by the wind to settle on exposed surface. At marine sites, the main corrodant in the air is sodium chloride which may be dispersed either as liquid aerosol or dry particles. It is known that the corrosion process can occur at relative humidities ${ }^{1}$ as low as $35 \%$.

Many of the complexities and difficulties inherent to atmospheric corrosion research stem from the great diversity of meteorological and pollutant condition that characterize the outdoor environment ${ }^{2}$.In polluted atmospheres, chlorides and $\mathrm{SO}_{2}$ are the common pollutants influencing metallic corrosion. Though chlorides come from natural airborne salinity, they are considered to be a significant pollutant as a consequence of their strong action on metals during atmospheric exposure. Relationships between chloride concentration in corrosion products, atmospheric salinity and corrosion rates have been reported ${ }^{3,4}$.In India, data regarding the relative corrosivity of atmospheres at varies cities ${ }^{5-10}$ are available along with that in USA, UK and other European countries ${ }^{11}$.

The present study was carried out in the marine atmosphere under outdoor exposure at Tithal (Dist. Valsad) situated in South Gujarat. This area is three metres above the mean sea level and about $0.25 \mathrm{~km}$ away from the Arabian Sea. 


\section{Experimental}

Metallic plates of $\mathrm{Al}, \mathrm{Zn}$ and MS were taken for testing. Size of all the plates was kept $12.5 \times 7.5 \times 0.18 \mathrm{~cm}$. Two types of time duration monthly and yearly were considered for the determination of corrosion rate. Before exposure, the plates were cleaned from rust by grinding and buffing to produce a homogeneous and reproducible surface. The frame was placed in parallel in fully exposed condition 10 feet above the ground level making an angle of $45^{\circ}$ towards the horizontal plane. Another set of MS plates were exposed vertically in fully outdoor condition.

After exposure period, test plates were wrapped in plastic bags and brought to the laboratory for cleaning. Every exposure was carried out in duplicate and mean of the two values are taken. Control sample plates were used to determine the loss of metal in the cleaning solution and the final figures of the loss in weight of exposed plates were corrected accordingly. Corrosion products on $\mathrm{Al}$ plates were removed by using a solution of concentrated $\mathrm{HNO}_{3}$ containing $\mathrm{CrO}_{3}$ (chromic acid $50 \mathrm{~g} / \mathrm{L}$ ) at room temperature for about 10 minutes ${ }^{12}$. Zinc plates were cleaned by solution made by dissolving $10 \% \mathrm{CrO}_{3}$ and about $0.2 \mathrm{~g}$ of $\mathrm{BaCO}_{3}$ in distilled water at $298 \mathrm{~K}$ for about 2 minutes ${ }^{13}$. Hudson used Clark's solution to remove the rust from mild steel which is prepared by dissolving $2 \%$ $\mathrm{Sb}_{2} \mathrm{O}_{3}$ and $5 \% \mathrm{SnCl}_{2}$ in concentrated $\mathrm{HCl}(100 \mathrm{~mL})$ at room temperature with constant stirring for about $15-20$ minutes $^{14,15}$.

The atmospheric salinity content ( $\mathrm{mg} \mathrm{NaCl} / \mathrm{sq} . \mathrm{dm} /$ month) in the air was assessed by adopting the same principle as that of the wet candle method described by Ambler and Bain ${ }^{16}$. The lead peroxide method is used for monitoring of $\mathrm{SO}_{2}$ contain in air described by $\operatorname{Diab}^{17}$.

\section{Results and Discussion}

\section{Meteorological parameters}

Monthly variation in temperature was observed and it was found that March to June are hot months, average maximum and minimum temperature are about $308 \mathrm{~K}$ and $290 \mathrm{~K}$ respectively; whereas December to February are cold months. Temperature and relative humidity data are shown in Figure 1. Generally, the rain starts in June continues up to October. Total annual rainfall was measured $1817 \mathrm{~mm}$ and $2114 \mathrm{~mm}$ in the year of 2006 and 2007 respectively.

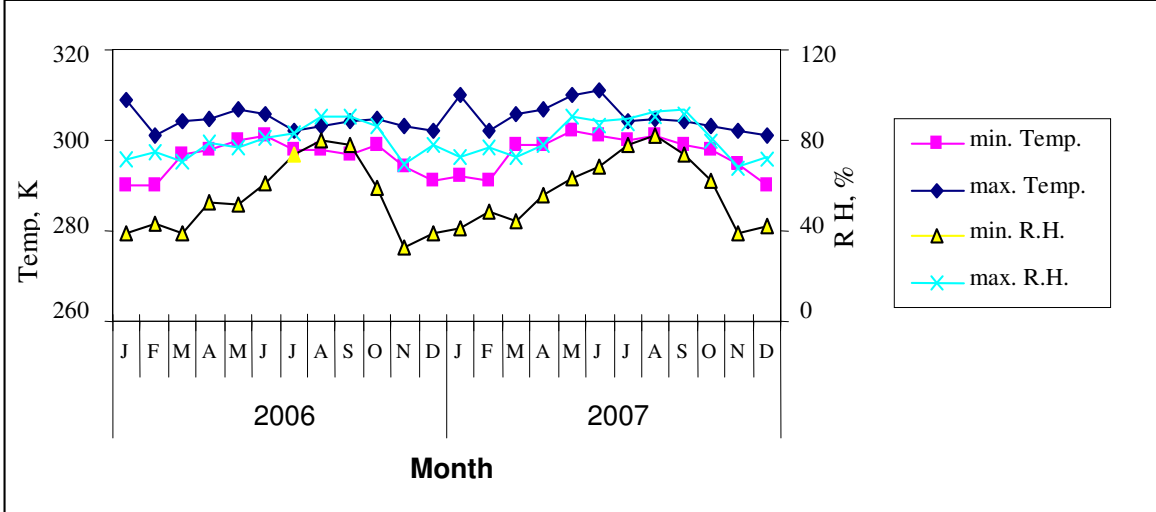

Figure 1. Minimum and maximum temperature and relative humidity at marine environment. 
Monthly atmospheric salinity rate was found to be in the range of 160 to 502 and 26 to $84 \mathrm{mg} \mathrm{NaCl} / \mathrm{sq} . \mathrm{dm} /$ month at exposure sites of 0.25 and $1.5 \mathrm{~km}$ from the sea respectively (Figure 2). Monthly salinity values are shown in Table 1. The data indicates that amount of salinity in the atmosphere decreases dramatically as distance increases from the seashore. An increase in salt content increases the rate of corrosion. Atmospheric salinity rate of different sites are reported as follows: 2 to $8 \mathrm{mg} \mathrm{NaCl} / \mathrm{sq} . \mathrm{dm} / \mathrm{month}$ at Cochin (marine) ${ }^{7}, 495$ $\mathrm{mg} / \mathrm{dm}^{2} \mathrm{Cl}$ (average 6 months) at Cuba (coastal station) ${ }^{18}$ and average $5.4 \mathrm{mg} \mathrm{NaCl} / \mathrm{sq} . \mathrm{dm} /$ month at Mumbai (industrial cum marine) ${ }^{5}$. A sulphation rate (Figure 3) measured at marine station was ranging from 9.6 to $19.8 \mathrm{mg} \mathrm{SO} / \mathrm{sq} . \mathrm{dm} / \mathrm{month}$ (Table 1). A sulphation rate of $0.03 \mathrm{mg} \mathrm{SO} / \mathrm{sq} . \mathrm{dm} /$ month is usually accepted as representative of clean air ${ }^{19}$. Sulphation rate was reported from 3 to $40 \mathrm{mg} \mathrm{SO} / \mathrm{sq} . \mathrm{dm} /$ month at Bombay (industrial cum marine) $)^{5}, 4$ to $10 \mathrm{mg} \mathrm{SO}$ /sq.dm/month at Kolkatta ${ }^{6}$ and $3.5 \mathrm{mg} \mathrm{SO} 3 / \mathrm{sq} . \mathrm{dm} / \mathrm{month}$ at Cochin (marine) ${ }^{7}$.

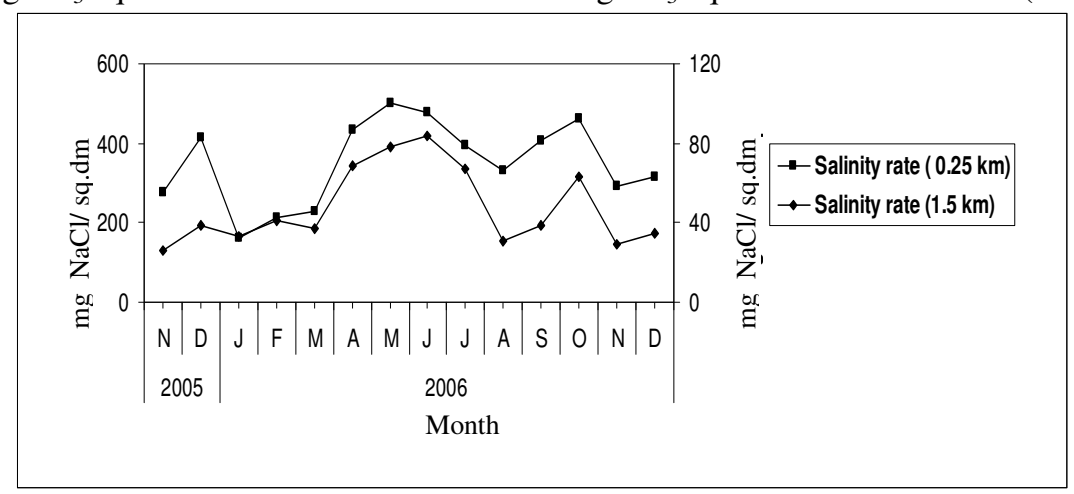

Figure 2. Atmospheric salinity rate of different distance from sea at marine environment.

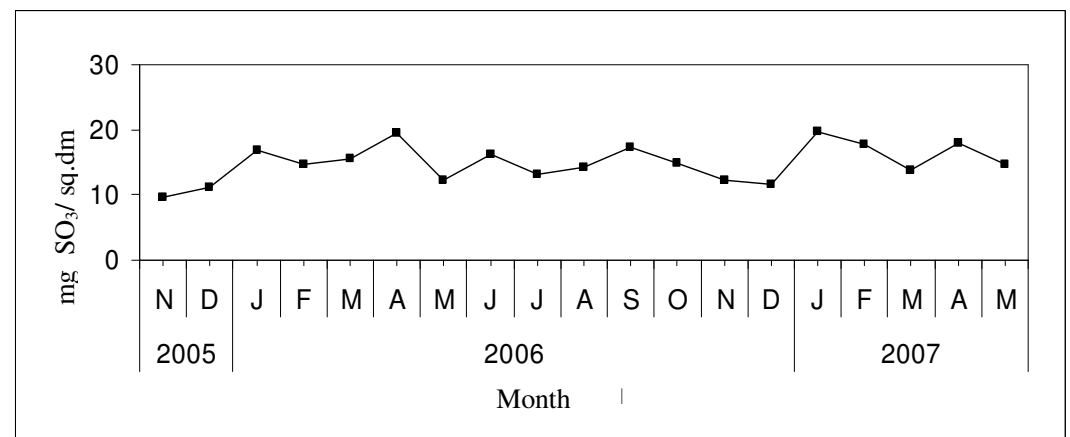

\section{Aluminium}

Figure 3. Sulphation rate at marine environment.

Monthly corrosion rate of $\mathrm{Al}$ was found in the range of 2 to $21.8 \mathrm{mg} / \mathrm{sq} . \mathrm{dm}$; whereas yearly corrosion rate was found in the range of 15.9 to $47.8 \mathrm{mg} / \mathrm{sq} . \mathrm{dm}$ (Figure 4). Minimum corrosion was observed in the monthly exposures from January to April and maximum corrosion was observed in June, July and August. The maximum corrosion was observed due to rain and salinity values also high. In outdoor exposure $\mathrm{Al}$ is attributed with the formation of more protective oxide film on the metal surface which might have offered protection to the metal from reacting which the surrounding environment. Chlorides are capable or breaking the passive film formed on the surface. This is very noticeable in the coastal station. 


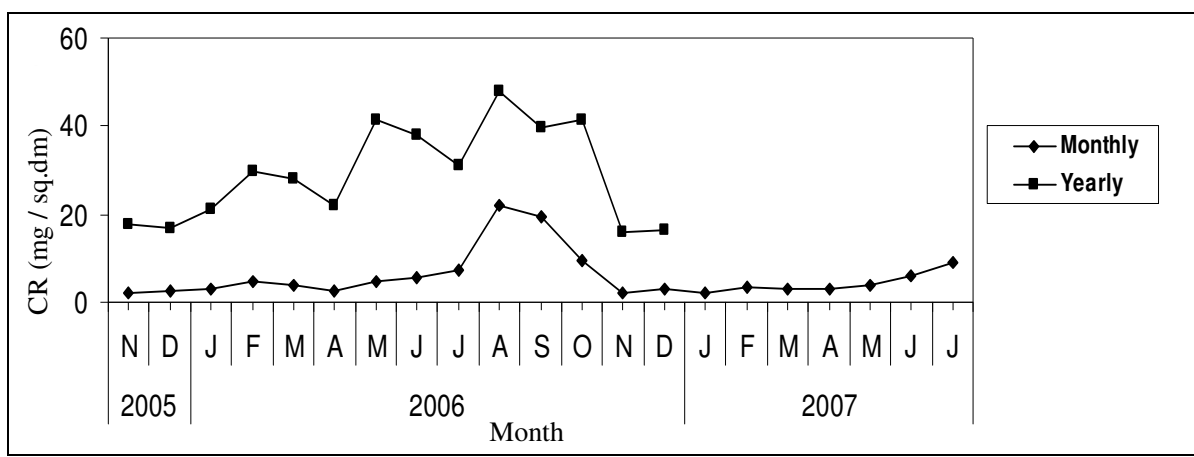

Figure 4. Monthly and yearly corrosion rate (CR) of aluminium under outdoor exposure during different months at marine environment.

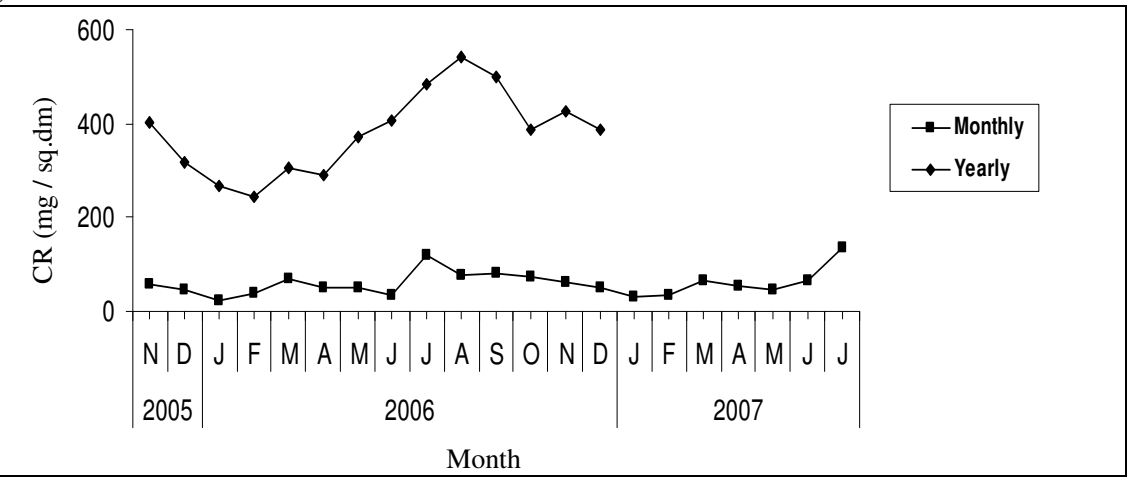

Figure 5. Monthly and yearly corrosion rate of zinc under outdoor exposure during different months at marine environment.

Table 1. Atmospheric salinity (in $\mathrm{mg} \mathrm{NaCl} / \mathrm{sq} . \mathrm{dm}$ ) and sulphation rate (in $\mathrm{mg} \mathrm{SO}_{3} / \mathrm{sq} . \mathrm{dm}$ ).

\begin{tabular}{lccc}
\hline \multirow{2}{*}{ Month } & \multicolumn{2}{c}{$\begin{array}{c}\text { Salinity rate } \\
\text { Distance from sea }\end{array}$} & $\begin{array}{c}\text { Sulphation rate } \\
\text { Distance from sea }\end{array}$ \\
\cline { 2 - 4 } & $0.25 \mathrm{~km}$ & $1.5 \mathrm{~km}$ & $0.25 \mathrm{~km}$ \\
\hline 2005 & & & \\
November & 278 & 26 & 9.6 \\
December & 414 & 39 & 11.1 \\
2006 & & & \\
January & 160 & 33 & 16.8 \\
February & 213 & 41 & 14.7 \\
March & 230 & 37 & 15.6 \\
April & 434 & 69 & 19.5 \\
May & 502 & 78 & 12.3 \\
June & 479 & 84 & 16.2 \\
July & 396 & 67 & 13.1 \\
August & 331 & 31 & 14.2 \\
September & 408 & 39 & 17.2 \\
October & 463 & 63 & 14.8 \\
November & 294 & 29 & 12.2 \\
December & 317 & 35 & 11.6 \\
\hline
\end{tabular}


Average seasonal corrosion rate of $\mathrm{Al}$ was obtained in the rainy months (55.3 $\mathrm{mg} / \mathrm{sq} . \mathrm{dm}$ ) is approximately 5 times higher compared to the corrosion rate in winter months (12.2 mg/sq.dm) and 3 times higher compared to summer months $(17.4 \mathrm{mg} / \mathrm{sq} . \mathrm{dm})$ respectively (Table 2). Monthly corrosion rate of aluminium indicates a close correlation with number of rainy days $(\mathrm{r}=0.68)$.

Table 2. Average seasonal corrosion rate (in $\mathrm{mg} / \mathrm{sq} . \mathrm{dm}$ ).

\begin{tabular}{lccc}
\hline \multirow{2}{*}{ Season } & \multicolumn{3}{c}{ Corrosion rate, mg/sq.dm } \\
& Aluminium & Zinc & Mild steel \\
\hline Winter & 12.2 & 354 & 573 \\
Summer & 17.4 & 167 & 1611 \\
Rainy & 55.3 & 299 & 2462 \\
\hline
\end{tabular}

Zinc

Monthly corrosion rate of $\mathrm{Zn}$ was found in the range of 24 to $134 \mathrm{mg} / \mathrm{sq} . \mathrm{dm}$; whereas yearly corrosion rate was found in the range of 244 to $541 \mathrm{mg} / \mathrm{sq} . \mathrm{dm}$ (Figure 5). Zinc probably corrodes fairly rapidly during the early stages of exposure, but the corrosion slow down quickly with the formation of the protection films. There is a general type of attack on $\mathrm{Zn}$ plates.

Average seasonal corrosion rate of $\mathrm{Zn}$ was obtained in rainy months (354 mg/ sq.dm) is 2 times higher compared to the values obtained in summer months (167 mg/sq.dm) (Table 2). Higher corrosion rate of $\mathrm{Zn}$ in rainy months may be due to the effect of rain. Monthly corrosion rate of $\mathrm{Zn}$ indicates a close correlation with rainfall $(\mathrm{r}=0.67)$ and number of rainy days $(r=0.56)$. The monthly corrosion rate of zinc has a close positive correlation with minimum relative humidity $(\mathrm{r}=0.72)$.

\section{Mild steel (MS)}

Monthly corrosion rate of MS was found in the range of 119 to $1132 \mathrm{mg} / \mathrm{sq} . \mathrm{dm}$; whereas yearly corrosion rate was found in the range of 2743 to $4286 \mathrm{mg} / \mathrm{sq} . \mathrm{dm}$ (Figure 6). The corrosion suffered by mild steel was mainly of a general type. Figure 5 indicates the minimum corrosion take place during November-2005 to January-2006 and January-2007. It was observed that the pollution values are also lower during this period, which indicates corrosion rate was affected by pollution.

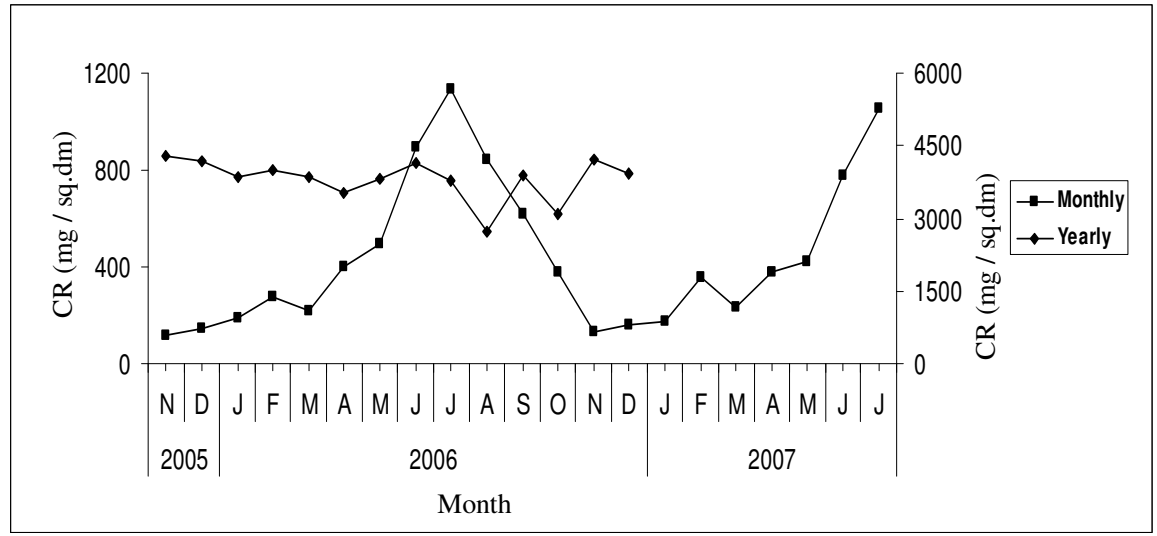

Figure 6. Monthly and yearly corrosion rate of mild steel under outdoor exposure during different months at marine environment. 
Average seasonal corrosion rate of MS was obtained in rainy months (2462 mg/ sq.dm) is higher compared to the values obtained in hot months $(1611 \mathrm{mg} / \mathrm{sq} . \mathrm{dm})$ (Table 2). Samples exposed in winter months indicate lower corrosion rate compared to rainy months. This suggests that protective film is formed on metal surface which can resist attack during subsequent exposure. Higher corrosion rate in rainy months may be due to the effect of rain. Monthly corrosion rate of MS indicates a close positive correlation with rainfall $(r=0.94)$ and number of rainy days $(\mathrm{r}=0.86)$. Monthly corrosion rate of MS indicates a weak correlation with sulphation rate $(\mathrm{r}=0.38)$. Monthly corrosion rate of mild steel indicates a close positive correlation with minimum humidity $(\mathrm{r}=0.85)$ and positive correlation with atmospheric salinity $(\mathrm{r}=0.68)$.

\section{Positional effect}

The results indicate that the plates exposed vertically suffer less corrosion than those exposed at an angle of $45^{\circ}$. Mild steel plates exposed from January-2006 to December2006, shows average value of $641 \mathrm{mg} / \mathrm{sq} . \mathrm{dm} / \mathrm{month}$ at vertical position and 556 $\mathrm{mg} / \mathrm{sq} . \mathrm{dm} / \mathrm{month}$ at an angle of $45^{\circ}$ position (Table 3 ). The reason was undoubtedly being the retention of moisture and atmospheric particles for longer periods on a panel exposed at an angle of $45^{\circ}$.

Table 3. Positional effect on corrosion rate of mild steel (MS).

\begin{tabular}{lcc}
\hline \multirow{2}{*}{ Month } & \multicolumn{2}{c}{$\begin{array}{c}\text { Corrosion rate } \\
\text { mg/sq.dm }\end{array}$} \\
\cline { 2 - 3 } & Vertical & At $45^{\circ}$ \\
\hline 2006 & & \\
January & 226 & 185 \\
February & 360 & 275 \\
March & 262 & 217 \\
April & 428 & 397 \\
May & 892 & 494 \\
June & 1335 & 889 \\
July & 1611 & 2131 \\
August & 1207 & 842 \\
September & 672 & 617 \\
October & 469 & 378 \\
November & 96 & 115 \\
December & 138 & 140 \\
\hline
\end{tabular}

\section{Conclusions}

Monthly corrosion rate ratio of MS : $\mathrm{Zn}$ is not constant and varies from a low of 2 to a high of 26; whereas yearly corrosion rate ratio of MS : $\mathrm{Zn}$ varies from a low of 8 to a high of 16 . Monthly corrosion rate ratio of MS : Al varies from a low of 32 to a high of 155; whereas yearly corrosion rate ratio varies from 57 to 264 . Monthly corrosion rate ratio of $\mathrm{Zn}$ : Al varies from a low of 6 to a high of 30, whereas yearly varies from a low of 8 to a high of 27 .

\section{Acknowledgements}

The authors are thankful to Department of Chemistry, Navyug Science College, Surat and C. U. Shah Science College, Ahmedabad for providing laboratory facilities. 


\section{References}

1. Fishman S G and Crowe C R, Corros Sci., 1977, 17, 27.

2. Lloyd B and Manning M I, Corros Prev Cont., 1991, 4, 29.

3. Corvo F, Corrosion, 1984, 40, 4.

4. Morcillo M, Chico B, Qtero E and Mariaca L, Mat Perf., 1999, 72.

5. Sanyal B, Nandi A N, Natarajan A and Bhadwar D, J Sci Ind Res., 1959, 18A, 127.

6. Sanyal B, Das Gupta B K, Krishnamurthy P S V and Singhania G K, J Sci Ind Res., 1961, 20D, 27.

7. Sanyal B, Balkrishnan A, Singhania G K and Menon U G K, J Sci Ind Res., 1962, 21D, 185.

8. Vashi R T and Patel R N, J Indian Chem Soc., 2004, 81, 680.

9. Vashi R T, Malek G M, Champaneri V A and Patel R N, Bull Electrochem., 2002, 18(2), 91.

10. Vashi R T and Patel R N, Bull Electrochem., 1996, 13(8-9), 477.

11. Hudson J C and Stanners J F, J Appl Chem., 1953, 3, 86.

12. Whitby L, Trans Faraday Soc., 1933, 29, 527.

13. Stroud E G, J Appl Chem., 1951, 1, 93.

14. Foran M R, Gibbons E V and Wellington $\mathrm{J} \mathrm{R}$, The measurement of atmospheric sulfur dioxide and chlorides, Chem in Canada, May, 1958.

15. Clarke S G, Trans Electrochem Soc., 1936, 69, 131.

16. Ambler H R and Bain A A J, J Appl Chem., 1955, 5, 437.

17. Diab R D, South African Journal of Science, 1978, 74, 378-381.

18. Mendoza A R and Corvo F, Cuba, Corrosion Sci., 2000, 42, 1123.

19. Thomas F W and Davidson C M, J Air Pollut Control Assoc., 1961 11(1), 24. 


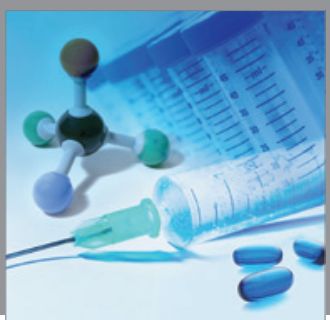

International Journal of

Medicinal Chemistry

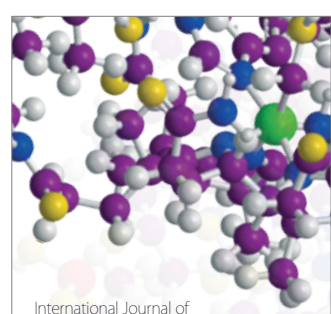

Carbohydrate Chemistry

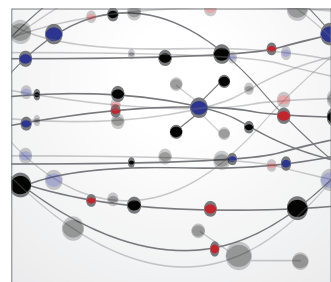

The Scientific World Journal
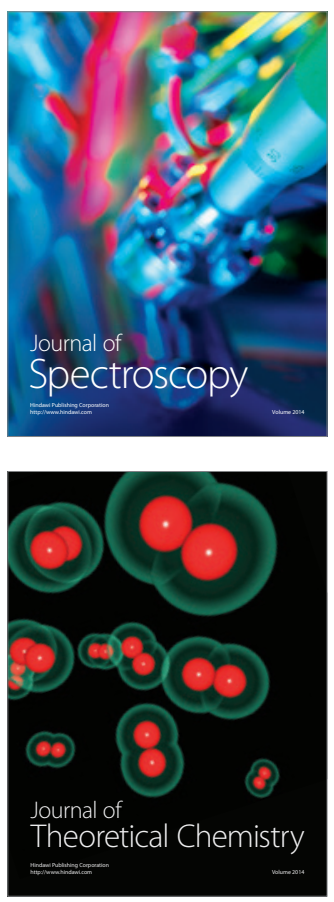
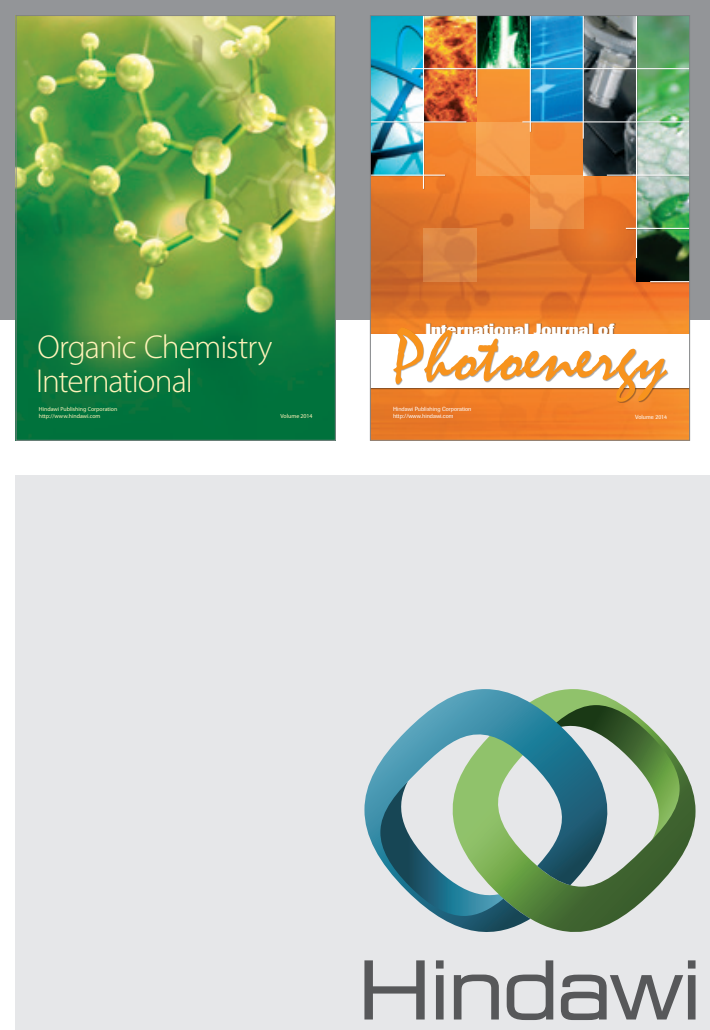

Submit your manuscripts at

http://www.hindawi.com
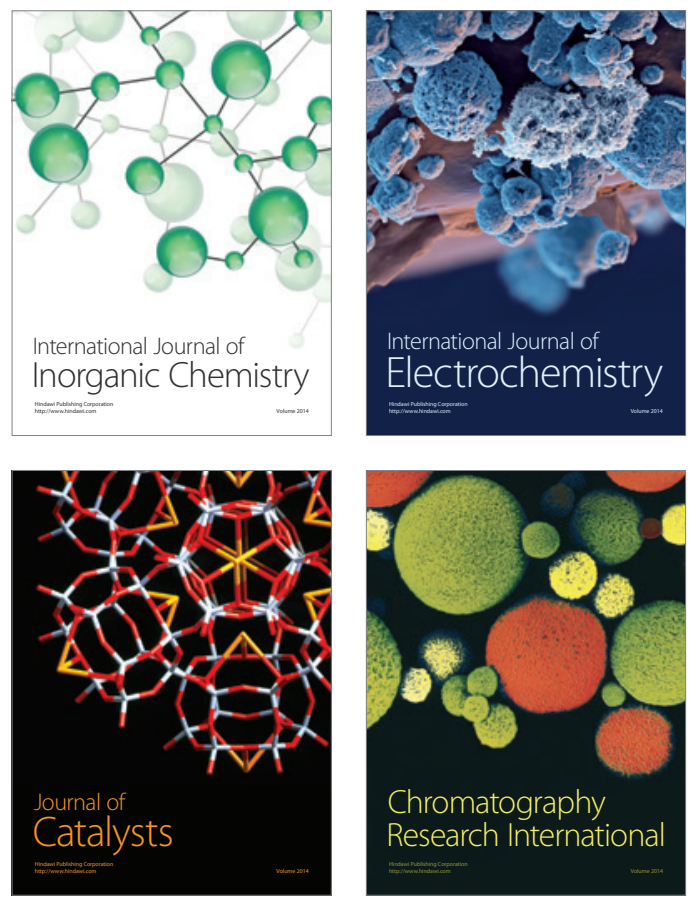
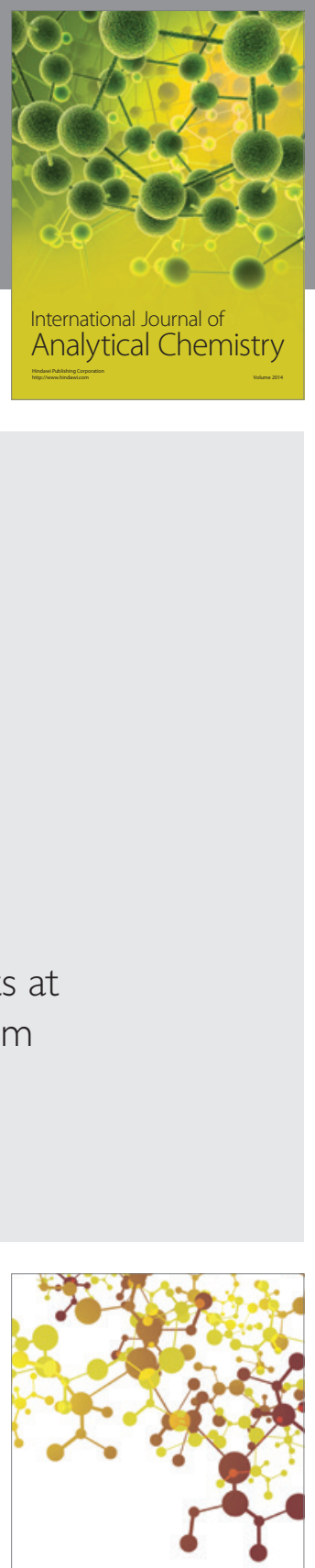

Journal of

Applied Chemistry
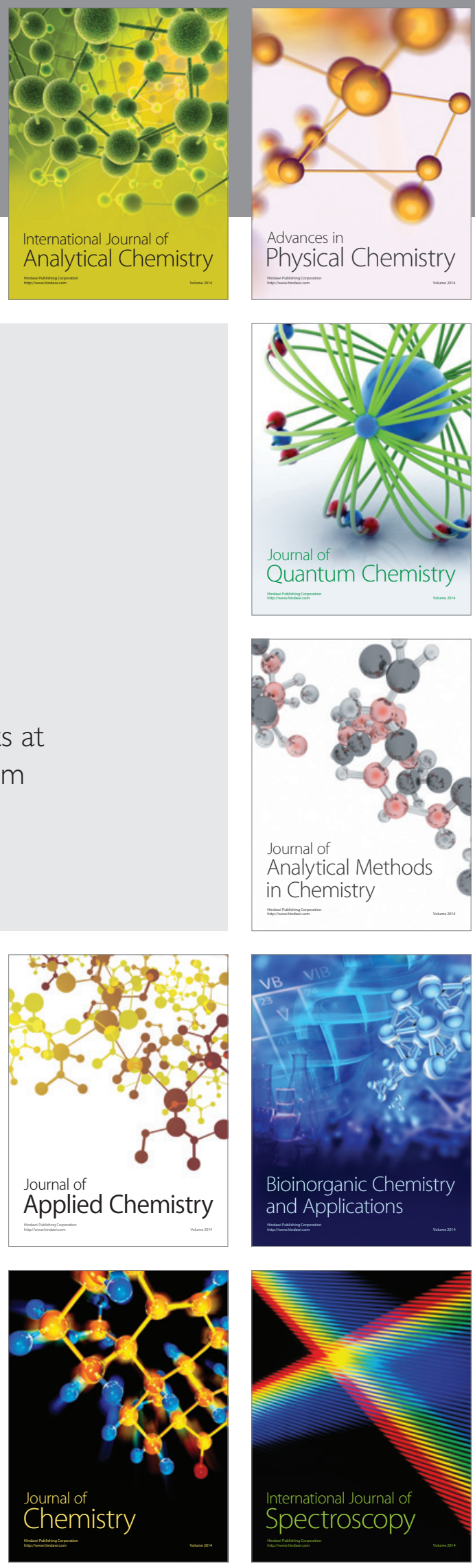